\title{
Implementation of Ecosystem Nanostructures as Indicators of the Processes on Agricultural Lands
}

\author{
Abumuslimov A.A. \\ Department of biological research, \\ Complex Scientific and Research Institute \\ named after Kh.I. Ibragimov of the Russian Academy of \\ Sciences: \\ Grozny, Russia \\ burum66@mail.ru \\ Baibatyrova E.R. \\ Department of biological and medical research, \\ Academy of Sciences of Chechen Republic \\ Grozny, Russia \\ elina-76-76@mail.ru
}

\author{
Alakhverdiev F.D. \\ Faculty of geography and geoecology \\ Chechen State University \\ Grozny, Russia
}

\author{
Abumuslimova I.A. \\ Department of biological and medical research, \\ Academy of Sciences of Chechen Republic \\ Grozny, Russia \\ indira_anchr@mail.ru
}

\author{
Bankurova R.U. \\ Faculty of geography and geoecology \\ Chechen State University \\ Grozny, Russia \\ b.larida@mail.ru
}

\begin{abstract}
The paper studies topical problems of land degradation taking place on the territories of irrigation systems. The authors attempt to propose the most promising approach to reveal transformations occurring on agricultural lands of northwestern Caspian Sea region.

The work implements geobotanical indicators as one of important indicators of changes to the environment.

The researchers analyze the nanostructure of vegetation cover on key plots dissipated along different channels in the seasons of the year, which allowed characterizing the studied territory with wide distribution of salinized clays lying at low depths.

Small fragments not engaged into sowing were investigated. The results demonstrate characteristic complexing of light-chestnut soils and solonetzic soils which coincides with the characteristic given to this irrigation massif by soil scientists.

It is shown that over the recent years, in northwestern Caspian Sea region, a lot of channels were built that are used not only for irrigation, but also for water supply of pasture massifs. All these measures allow improving the water supply of pastures and haying lands.

The paper gives estimation and recommendations in terms of contemporary state of the natural-resources potential of lands in the northwestern Caspian Sea region on the basis of ecological principles and for their improved yield.
\end{abstract}

Keywords- soil salination, filtration, indication, nanostructure, irrigation channel, landscape.

\section{INTRODUCTION}

The global climate change and intense desertisation pose a serious problem of development and implementation of effective control over the natural-resources potential (NRP) that allows rejecting resource-consuming technologies and flexibly manipulating the level of anthropogenic load on ecosystems and preserving soil and vegetation resources of arid lands [5]. Indeed, the disturbance of biogeochemical cycles - caused by non-rational exploitation of natural resources, irresponsible intervention of the human in naturepromotes the degradation of environment all over the world.

The responsibility of the human for creation of crisis situations in the nature motivates the scientists, politicians and other activists in different countries to unite their efforts on constructive solution of the problems of resources and environment. For example, the strategies elaborated by international community and fixed in international documents "Sustainable development of society. Agenda for XXI century" (1993), "UN Convention on protection from desertisation" (1994), "Convention on preservation of biological diversity" (1997), are aimed at the development of measures decreasing the desertisation threat from climatic and anthropogenic factors, increasing the biodiversity and life quality and are specifically topical for the northwestern Caspian Sea region, which is the subject of our study $[1,2]$.

According to the data of V.I. Petrov, in the northwestern Caspian Sea region, degraded pastures are dominating which 
lack about $888 \mathrm{~K}$ tons of fodder units [6]. The intense exploitation of the ecosystems, used without accounting of natural conditions, resulted in developed desertisation and degradation of vegetation cover on $60 \%$ of the region territory and decreased biodiversity and yield.

Insufficient knowledge of implementation of ecosystem nanostructures to analyze the processes occurring in the northwestern Caspian Sea region determines the topicality of our studies. The paper is aimed at proposing the most promising approach to reveal transformations occurring in agricultural lands of the northwestern Caspian Sea region and elaborate the scientific and practical principles for using nanostructures to indicate the inherent processes.

\section{METHODS AND MATERIALS}

Undoubtedly, the indication of processes on agricultural lands is one of the important directions of practical implementation of geobotanical indicators as marks of alterations to the environment. As of today, this direction is understudied. Some steps on the way to solve this problem were made on the example of the research of cultivation land inclined to the channels in the lower reach of river Talovka (Republic of Dagestan) and partially for agricultural lands of the Republic of Kalmykia, where irrigation is widely used, but its state cannot be always considered as satisfactory. Here, the irrigated massifs are represented by large irrigation systems, plots with inundation irrigation and small ameliorant massifs. The majority of the channels go through earth stream courses, which conditions substantial losses due to filtration. The drainage systems are partial, which leads to secondary salination. The main task of ameliorators on this territory is drainage loss. For instance, for Sarpinsky irrigation system in Kalmykia, the Davaskiy evaporation water body was designed, which would take enormous area, but according to the calculations, the territory would had been transformed into salinated soil and ponds. That is why the project was never executed. Similarly to this case, the project of drainage loss into Kizlyar Bay was rejected. Thus, the problem of excess salts in the irrigation area cannot be considered solved.

By studying various types of agricultural development of the territory under investigation, we have noted that the largest anxiety is caused by rice sowing, because on the rice bays, the widely spread salination is accompanied by bogginess.

According to the Yuzhgiprozem Institute, studying the consequences of irrigation, $90 \%$ of the soil of the Caspian Sea system was recognized as unfavorable, and $67 \%$ of that in Sarpinskaya system. The degradation of these territories is a serious threat for agricultural production. According to scientists, agronomes and practical plant breeders, the secondary salination caused by irrigation systems considerably reduces the fertility of such lands for 15-20 years and can lead to substantial shift of soil and vegetation condition.

All these facts necessitate the revision of the most traditional conceptions on implementation of irrigation systems and character of land exploitation. The application of advanced research technologies for surveying these territories becomes vital and expands the capabilities of their sensible control.
All these facts necessitate the revision of the most traditional conceptions on implementation of irrigation systems and character of land exploitation. The application of advanced research technologies for surveying these territories becomes vital and expands the capabilities of their sensible control.

\section{RESULTS}

Our studies were carried out on key plots dissipated along different channels in Sarpinskaya system: we studied depressions Bezhemin-Goul, Budun-Khuduk and inundation massif Bolshoy Tsaryn. We intentionally studied cultivated lands and small plots of uncultivated ground for the sake of comparison. We inspected such plots in different seasons: in summer during abundant growing of crops, in early fall after gather, which allowed analyzing the nanostructure of the vegetation cover of plots on which the crops developed. The studied territory was characterized by wide distribution of salinized clays lying at low depths. According to three soil sections, the supresurface of clays was uncovered at a depth of 2.3-3.5 meters; they were appreciably mineralized (Table 1).

The clays often contained layers of sand. Additional sections made on the plots for cropping rice and corn (after gather) have shown formation of irrigation silt and suspended water at very shallow depth, about $0.5-1.0 \mathrm{~m}$. It was noted on corn crops where flooding, in contrast to rice, is periodical, rather than constant.

TABLE I. ANALYSIS OF GROUND WATERS IN MASSIF BOLSHOY TSARYN

\begin{tabular}{|c|c|c|c|}
\hline$\frac{\dot{0}}{\frac{\theta}{0}}$ & Plot appearance & $\begin{array}{l}\text { Depth of } \\
\text { ground } \\
\text { water [m] }\end{array}$ & Mineralization [g/l] \\
\hline 1. & $\begin{array}{l}\text { Flat surface with } \\
\text { wormwood association } \\
\text { with Kochia prostrata }\end{array}$ & 2.3 & 27.2 \\
\hline 2. & $\begin{array}{l}\text { Shallow gully } \\
\text { Wormwood association } \\
\text { with Limonium Gmelini } \\
\text { and Atriplex verrucifera }\end{array}$ & 2.8 & 31.2 \\
\hline 3. & $\begin{array}{l}\text { Funnel depression with } \\
\text { wormwood and needle } \\
\text { grass }\end{array}$ & 3.5 & 25.1 \\
\hline
\end{tabular}

The studies of small fragments not involved in cropping demonstrated that this territory is characterized by combination of light-chestnut and solonetzic soils, which coincides with the characteristic given to this irrigation massif by soil scientists. Due to fairly fractional combination of soils, the irrigation is not differentiated which leads to uniform inundation of less and more salinized soils. Obviously, in solonetzic soils formed in the spots where the salinized clays lay at lower depth, the filtration is impeded, and these are the most favorable spots for formation of irrigation suspended water, which shallow position conditions secondary salination. The latter manifests in the structure of sowing massifs. In the spots where the suspended water lies almost at the surface, the crops (after gather) demonstrate specific slight depressing with microcoenosis of hyperhalophytes and hygrophilous tallgrass. We did not completely explain the genesis of these 
depressions, but we can suggest that close situation of suspended water and poor filtration, as well as accumulation in the closest to the surface sand layers causes their wash out, removal of the finest fractions and, consequently, decrease of their volume. This, in turn, explains the depression of clay surfaces and formation of hardly evident nano-depressions. The latter demonstrate the formation of specific fragments of various associations that can be divided into four groups: a) monodominant reedstand; b) fragments of shoreweed associations; c) fragments of salicornioid and ClimacopteraPetrosimonia associations; d) fragments of Halosta-chys caspica and shoreweed-tamarix association.

In the first group dominate hygrophytes with wide range of salination; in the second, the associations of saline meadows; in the third, grassy hyperhalophytes; in the fourth, bushy halophytes. The fall of single specimens of Tamarix meyeri and Halosta-chys caspica introduces into the soils a considerable amount of salts [3], so, under the leafage of these species concentrate Climacoptera and saltwort. There is determined domination of different fragments on different sowing massifs. In a number of cases, this is clearly evident even during visual check of a crop. Indeed, the presence of afore described groups is discovered by reed that often outstands over the crops, even over corn or sunflower. The fragments of associations with Tamarix and Halosta-chys caspica are evident, because their plants are fairly large, and around them, miniature glades form, since the development of cultivated plants is suppressed by high salination.

Grassy hyperhalophytes and fragments of saline meadows are barely visible and manifest only at careful visual inspection of crops and only near edges and along the periphery; however, in the fall they become aerovisual. In general, we were able for classify the crops into groups in terms of separate dominating nanoelements. On the massifs with domination of different nanoelements we used manual boring to open and sample suspended water. The boring sites were in the centers of corresponding massifs. Three massifs were bored with domination of different groups of nanoelements (Table 2).

The domination of various nanoelements with the background of crops can serve as a reference of suspended water salination and, probably, total salination of soils. Noteworthily, according to our observations, in all crops, corn was depauperated, thinned with many gaps, where it was absent.

According to these data, in the fourth group, there were small plots of real puffed solonchak. On old abandoned sowing plots subjected to severe salination, undividedly dominated Tamarix meyeri and Halosta-chys caspica. The afore mentioned groups of nanoelements assemble into an association, which members replace each other with increasing salination. Notably, the combinations of saline shrubs and subshrubs turn out to be the latest and most longstanding members of the association. After initially appearing as separate macroplots they start rapidly spreading on the fields left after agricultural exploitation.

A certain significance for indicating the salination have small aggregations of plants different in appearance and phenophase from the background formed by the population of this type. For example, the groups of corn specimen growing in nanodepressions are noted for low height, etiolation and little leaf. These peculiarities were more pronounced for grain crops. Rice had no visual deviations.

TABLE II. CHARACTERISTICS OF SUSPENDED WATER UNDER CORN AND SUNFLOWER CROPS IN IRRIGATION MASSIF BOLSHOY TSARYN

\begin{tabular}{|c|c|c|c|}
\hline$\frac{\dot{z}}{\dot{a}}$ & Massif nature & $\begin{array}{c}\text { Depth of suspended } \\
\text { water }[\mathrm{m}]\end{array}$ & $\begin{array}{c}\text { Boundary } \\
\text { mineralizatio } \\
\text { n values [g/l] }\end{array}$ \\
\hline 1. & $\begin{array}{l}\text { Crops with domination } \\
\text { of reed cenosis } \\
\text { fragments }\end{array}$ & $0.2-0.5$ & $4.0-9.6$ \\
\hline 2. & $\begin{array}{l}\text { Crops with domination } \\
\text { of saltwort, } \\
\text { Climacoptera and } \\
\text { Petrosimonia }\end{array}$ & $0.3-1.0$ & $11.0-27.0$ \\
\hline 3. & $\begin{array}{l}\text { Crops with domination } \\
\text { of nanodepressions } \\
\text { with association of } \\
\text { shoreweed }\end{array}$ & $0.6-1.5$ & $18.0-27.8$ \\
\hline 4. & $\begin{array}{l}\text { Crops with fragments } \\
\text { of associations of } \\
\text { Tamarix, Halosta-chys } \\
\text { caspica and saltwort }\end{array}$ & $1.0-2.3$ & $24.6-41.3$ \\
\hline
\end{tabular}

Over last 50 years, in northwestern Caspian Sea region, a lot of channels were built that are used not only for irrigation, but also for water supply of pasture massifs. For instance, Chernozemelsky irrigation system improved $100 \mathrm{~K}$ ha of pasture and haying lands. The RF Government pays appreciable attention to the issue of rational resource use of so-called Black Soils (Chernozemelsky district), Kizlyar pastures, Terek sand massif, which is reflected in both federal and regional documents. The situation requires establishing pasture rotation with fencing and rotational grazing. For dense ground we recommend using band tillage by blade cultivators (band width about 10 meters and the same spaces between them) and sowing of rye and Sudan grass in the first years, and then sowing of perennial grasses over the remains of the annual crops. Improved pastures and developed animal husbandry require advancement and expansion of irrigation system. The largest threat is posed by the filtration from the channels made in stream courses. The problems of indication of this phenomenon are enlightened in the works of S.V. Viktorov [4].

We only note that the sideway filtration can be detected even in the earliest moments of origination by certain peculiarities of the nanorelief in combination with indicating plants. Our studies in the region of Talovskiy groups of channels and Chernozemelsky channel have shown that the sideway filtration has advanced comparatively far. We unveiled ecological relics of previous earlier stages of sideway filtration manifestation. The analysis has confirmed that the earliest evidence of active sideway filtration is appearance of tiny flow slides (in groups) on the sides of channels slightly above the maximum water level. On the test plot of $16 \mathrm{~m}^{2}$ we have counted from 3 to 5 flow slides with the length of $0.5-$ 1.5 meters and width of no more than 0.5 meters. Due to these parameters we termed them nano-slides. They differ in the 
material sliding as depressed gully or duct and accumulation of slid material forming a lip on the lower part of the gully. Such flow slides can be seen on the lower parts in clays, loams, heavy sandy loams; however, they do not occur in light sandy loams and sands. Under the nano-duct, appear the fragments of cane-cattail-reed associations with inclusion of flowering rush, bur reed and water plantain forming a narrow twisted band perpendicular to the direction of the channel and having length of 5 meters and more and width up to $1 \mathrm{~km}$. With the distance to the channel they thin out. In the irrigated massif of Bezhemin-Goul, we observed maximum distance of separate samples of reed, cattail, water plantain standing in 7$11 \mathrm{~m}$ from the channel side, propagating as a (solid) narrow band for 2 to 4 meters.

Trenching digging (2-3 meters long and 1 meter wide) show almost completely running soil that penetrated the cenosis of hydrophilic plants down to the depth of $1.5-3.0 \mathrm{~m}$. On parallel reference trenches where the flow slides were absent, there were no hydrophilic plants; the soil was wet and sometimes viscous, but not running. On the plots with running soil, the watering of the soil increased with the depth, and at the depth of 1.5 meters below the level of water in the channel, the trench was flooded by running mass of soil, while in reference plots, the soil remained wet, but not running. Thus, we can conclude that the plots with the most active filtration are clearly denoted by the afore described indicators. Their abundance allows distinguishing the sections of the channel with the largest losses. The filtration occurs along the whole channel, but in growth places of the said cenosis it is most pronounced. Noteworthily, the non-rational use of irrigation water for irrigation tillage and filtration threats undetected on time cause colossal losses for agricultural enterprises: large areas of land become salinized and bogged; land becomes infertile and drops out of agricultural rotation.

\section{CONCLUSIONS}

Thus, modern indication methods of territory survey in the zones of irrigation systems allow assessing the contemporary state of natural-resources potential of the territories in market conditions. They also enable the technologies for restoring the disturbed landscapes on the basis of ecological principles to increase their productivity. Yet, the largest economical effect from the indication methods for surveying territories of irrigation systems is provided by comprehensive implementation of control over negative consequences of the system of ameliorative measures.

\section{References}

[1] F.D. Alakhverdiev, A.A. Abumuslimov, State and modern dynamics of sandy landscapes of northwestern Caspian Sea region (in Russian). Grozny: AS ChR, 2012, p. 243.

[2] F.D. Alakhverdiev, A.A. Abumuslimov, R.U. Bankurova, "Strategy of implementation of landscape indicators to forecast the dynamics of steppes with domination of clay soils" (in Russian), Bulletin of Academy of Science of Chechen Republic, 2014, No. 2, pp. 105-110.

[3] N.I. Akzhigitova, Halophilic vegetation of Central Asia and its indication properties (in Russian). Tashkent, 1982, p. 148.

[4] S.V. Viktorov, Landscape indicators of hydroecological and engineering-geological conditions in irrigation regions and inundation of deserts (in Russian). Moscow, 1976, p. 56

[5] V.P. Voronina, "Detection and mapping of agroclimatic anomalies in northwestern Caspian Sea region" (in Russian), Bulletin of Saratov SAU named after N.I. Vavilov, 2009, No. 2, pp. 8-12.

[6] I. Petrov, "Peculiarities of desertisation and forest-amelioration of pastures of Caspian Sea region" (in Russian), 11-15 November, Moscow: Institute of Soil Science of MSU and RAS, 1999, pp. 368-392. [Scientific conference on Desertisation, 1999]. 